\title{
Proximate composition of the edible part of purple passion fruit and santol and in vitro prebiotic activity of crude polysaccharide extracts
}

\author{
${ }^{1}$ Wongsariya, K. and ${ }^{2, *}$ Kanchanadumkerng, $\mathrm{P}$. \\ ${ }^{1}$ Department of Biology, Faculty of Science, King Mongkut's Institute of Technology Ladkrabang, Bangkok \\ 10520, Thailand \\ ${ }^{2}$ Department of Food Chemistry, Faculty of Pharmacy, Mahidol University, Bangkok 10400, Thailand
}

\author{
Article history: \\ Received: 11 November 2020 \\ Received in revised form: 4 \\ January 2021 \\ Accepted: 8 March 2021 \\ Available Online: 27 June \\ 2021
}

Keywords:

Passion fruit,

Santol,

Dietary fibre,

Crude polysaccharide,

Prebiotic,

Probiotic

\section{DOI:}

https://doi.org/10.26656/fr.2017.5(3).657

\begin{abstract}
This study aimed to evaluate the functional and prebiotic properties of the edible portions of certain tropical fruits in Thailand, passion fruit and santol. The proximate composition of passion fruit and santol were analysed which total carbohydrate was the major component in both samples. Total dietary fibre of passion fruit and santol was 44.81 and $26.82 \%(\mathrm{w} / \mathrm{w})$, respectively, with the majority of insoluble dietary fibre. Soluble dietary fibre of both fruits was extracted by hot water and water-extractable polysaccharide was yielded at $16.47 \%$ and $25.24 \%(\mathrm{w} / \mathrm{w})$ for passion fruit and santol, respectively. The functional properties of fruit fibre were informed, with the satisfactory oil holding capacity of santol polysaccharide. The effect of both fruit polysaccharides on proliferation number at $24 \mathrm{hrs}$ was not different from inulin. Prebiotic activity score of fruit polysaccharide was calculated from the growth of Lactobacillus acidophilus and Bifidobacterium longum compared with the growth of the enteric pathogen, Escherichia coli corresponding to -0.25 and -0.23 for passion fruit and 0.10 and -0.01 for santol, respectively. In conclusion, both passion fruit and santol polysaccharide showed a distinct effect on the supportive growth of probiotic bacteria which may be potential candidate ingredient incorporated in probiotic food. From this evidence, the development of fruitbased synbiotics from passion fruit and santol migh be affordable.
\end{abstract}

\section{Introduction}

Fresh tropical fruits are consumed daily in the local diet as a delightful refreshment. Moreover, are considered a healthy food because they contain bioactive and nutritional constituents such as polysaccharides, vitamins, natural antioxidants, phytochemicals and are likely the cause of prevention of some diseases and cancers (Maria do Socorro et al., 2010; Quirós-Sauceda et al., 2014). Many plant-based foods especially fruit and vegetable favour a variety of health benefits according to their dietary fibre content. Dietary fibre (DF) is the edible part of plants or carbohydrate polymers that are resistant to digestion and absorption in the human small intestine with complete or partial fermentation in the large intestine (Brownlee, 2011). It exerts physiological function by the modulation of gut microbiota called prebiotic effects. These prebiotics deliberate certain soluble fermentable fibre which provides selective utilization by the beneficial host microorganisms and support health (Gibson et al., 2017). Several studies demonstrated that the edible parts of fruit have shown prebiotic properties including date palm (Al-thubiani and Khan, 2017), bambangan (Al-Sheraji et al., 2012), guava (Thuaytong and Anprung, 2011; Lim et al., 2018), lychee (Fasawang and Anprung, 2014), and longan (Thitiratsakul and Anprung, 2014), pitaya and jackfruit (Wichienchot et al., 2015).

Among the desired tropical fruits, passion fruit is rich in several bioactive compounds such as carotenoids, vitamins, phenolic compounds, and fibres. There are two popular types of passion fruits namely the yellow passion fruit (Passiflora edulis f. flavicarpa Deg) and purple passion fruit (Passiflora edulis f. edulis) (Corrêa et al., 2016; Lascano et al., 2020). Though most studies are based on yellow passion fruits on the available data of their chemical, physico-chemical, technological, and pharmacological activities such as antibacterial and antioxidant properties (Martínez et al., 2012; LópezVargas et al., 2013). While the purple passion fruit, which is commonly freshly eaten in Thailand, has limited study. Santol (Sandoricum koetjape Merr.) is another popular seasonal fruit in Thailand. Santol is an 
ethnobotanical plant used as a folk medicine for antiinflammatory and anti-colic activities using root and stem bark decoction (Nassar et al., 2010). Santol fruits and juices have antioxidant and antibacterial activities (Anantachoke et al., 2016; Toobpeng et al., 2017). However, the study on the edible portion of santol fruit is limited especially on the effects on beneficial bacteria or probiotics. Conventionally, prebiotic effects refer to selectively enhancing the growth of bifidobacteria or lactobacilli which is expected to be profitable to produce substrates as prebiotic (Verspreet et al., 2016). Recently, Lascano et al. (2020) have developed the synbiotic powder containing Lactobacillus plantarum and yellow passion fruit juice powder with probiotic stability and sensory acceptability. Nevertheless, most studies on santol and passion fruit have focused on dietary fibre from waste and by-products but no information about edible portion as potential prebiotic yet.

In this study, the edible portions of passion fruit and santol were yielded for dietary fibre by hot water extraction. The fruit fibre was evaluated for the proliferative effect of selected probiotic strains compared to the common enteropathogenic bacteria. Moreover, its technological properties offered functionality to the host's health such as water-holding capacity (WHC), oilholding capacity $(\mathrm{OHC})$, and cation exchange capacity (CEC) was determined. The fruit fibre extraction that focuses on soluble fermentable polysaccharide may indicate the potential of passion fruit and santol to valueadded as a prebiotic ingredient or used as a probiotic carrier in functional food development.

\section{Materials and methods}

\subsection{Sample preparation}

Fresh fruits of santol and passion fruit were purchased from the local market and store in Bangkok, Thailand. The fruits were cleaned with water and manually separated for their edible parts. Passion fruit was cut in half and spooned for its seed and pulp. For santol, the peel was removed and its inner flesh without the seed was collected. Then, the edible portions were dried in a hot air oven at $60^{\circ} \mathrm{C}$. The dried samples were grounded with a food homogenizer and kept in a desiccator until analysis was performed.

\subsection{Proximate analysis and dietary fibre content assay}

The moisture, ash, fat, and protein content of the edible part of the passion fruit and santol were determined by the Association of Official Analytical Chemists (AOAC) method of analysis and expressed in percentage (wet weight basis) (Horwitz and Latimer Jr., 2012). Fresh fruits were analysed for moisture content at $105^{\circ} \mathrm{C}$ using a moisture analyser (MA50.R model, Radwag, Poland). Total ash was determined as weight loss after incineration at $550^{\circ} \mathrm{C}$ for $5 \mathrm{hrs}$. Crude protein was estimated by the Kjeldahl method with a factor of 6.25. Crude fat was determined using solvent extract apparatus and petroleum ether as solvent. Total carbohydrate was calculated by difference using the equation:

Total carbohydrate $=100-($ weight in grams [protein + fat + water + ash] in $100 \mathrm{~g}$ of food)

Insoluble, soluble, and total dietary fibre of moisture -free, and fat-free and its fat content exceed $10 \%(\mathrm{w} / \mathrm{w})$, were determined according to the enzymatic-gravimetric method of the AOAC using Megazyme assay kit. Total dietary fibre was calculated by summation of insoluble and soluble dietary fibre. This commercial kit is based on AOAC method 985.29.

\subsection{Crude polysaccharide extraction}

Fruit fibre was retrieved by hot water extraction according to Tadayoni et al. (2015) with minor modification. Briefly, the sample was mixed with water at a ratio 1:3 and stirred on a hot plate magnetic stirrer. Then, the sample was extracted with hot water at $90^{\circ} \mathrm{C}$ for $3 \mathrm{hrs}$. The fruit polysaccharide was filtered using layers of cotton cheesecloth, then submitted to concentrate by rotary evaporator under reduced pressure of $60^{\circ} \mathrm{C}$. The water-soluble polysaccharide was dried by lyophilization and then the powder was weighed to calculate the yield of extraction and stored in a desiccator until the experiment.

\subsection{Functional properties of fruit polysaccharide}

Water-holding capacity (WHC), oil-holding capacity (OHC), and cation exchange capacity (CEC) were analysed for the functionality of fruit polysaccharide (Requena et al., 2016). For WHC, the sample was mixed with distilled water at a ratio of 1:10 and left for $24 \mathrm{hrs}$, then centrifuged at $1,006 \times \mathrm{g}$ for 30 mins. Volume was measured and WHC was expressed as $g$ of water held by $\mathrm{g}$ of sample. $\mathrm{OHC}$ was determined by mixing $0.1 \mathrm{~g}$ of sample with $1 \mathrm{~mL}$ of commercial olive oil, then the suspensions were centrifuged. $\mathrm{OHC}$ was expressed as $\mathrm{g}$ of oil held per $\mathrm{g}$ of sample. CEC was determined by mixing $0.5 \mathrm{~g}$ of sample with $5 \mathrm{~mL}$ of $2 \mathrm{~N} \mathrm{HCl}$ and incubated at room temperature for $24 \mathrm{hrs}$, then centrifuged at $2,200 \times g$ for $30 \mathrm{mins}$ and washed with saturated $\mathrm{NaCl}$ solution. The residue was suspended and titrated with $0.1 \mathrm{~N} \mathrm{NaOH}$. The titrant was calculated in milliequivalents $(\mathrm{mEq})$ and the CEC was expressed in $\mathrm{mEq}$ per $\mathrm{g}$. 
2.5 Analysis for prebiotic properties of the fruit polysaccharide

The prebiotic activity of fruit polysaccharide was evaluated in vitro by the growth of intestinal bacteria associated with health as described by Fissore et al. (2015). Bacterial cultures used in this study were standard JCM strains (equivalent to ATCC strains) which from human origin: Lactobacillus acidophilus JCM 1132 (=ATCC 4356 ${ }^{\mathrm{T}}$ ), Bifidobacterium longum JCM $1217\left(=\right.$ ATCC $\left.15717^{\mathrm{T}}\right)$, and Escherichia coli ATCC $11775^{\mathrm{T}}$. Bacteria were streaked onto MRS agar for $L$. acidophilus, MRS agar supplemented with $0.05 \%$ $\mathrm{L}$-cysteine $\mathrm{HCl}$ for $B$. longum and tryptic soy agar (TSA) for E. coli, then incubated at $37^{\circ} \mathrm{C}$ for $24-48 \mathrm{hrs}$. For $B$. longum, the culture was incubated in an anaerobic chamber (Oxoid) under an anaerobic atmosphere (Anaerocult A, Merck). After that, a single colony of $L$. acidophilus and $B$. longum was transferred into $5 \mathrm{~mL}$ of MRS and $5 \mathrm{~mL}$ of MRS broth supplemented with $0.05 \%$ L-cysteine $\mathrm{HCl}$, respectively, while a single colony of $\mathrm{E}$. coli was grown in $5 \mathrm{~mL}$ of tryptic soy broth (TSB), and incubated at the same condition as stated above. The assay was performed by adding $1 \%(\mathrm{v} / \mathrm{v})$ of overnight culture to another tube containing specific media broth with $1 \%(\mathrm{w} / \mathrm{v})$ glucose or $1 \%(\mathrm{w} / \mathrm{v})$ fibre samples. Specific media broth was MRS broth, MRS broth supplemented with $0.05 \%$ L-cysteine $\mathrm{HCl}$, and $\mathrm{M} 9$ minimal medium for $L$. acidophilus, B. longum, and $E$. coli, respectively. At 0 and $24 \mathrm{hrs}$ of incubation, samples were enumerated in duplicate using the serial dilution method and the results were calculated as colony forming units per milliliter $(\mathrm{CFU} / \mathrm{mL})$. Each assay was replicated a minimum of three times.

To assess the selectivity of the substrates, prebiotic activity score (PAS) was determined according to the equation of Huebner et al. (2007). Inulin was used as the standard for comparison.

Prebiotic activity score (PAS) $=[\Delta(\log C F U / m L)$ probiotic at 0 and $24 \mathrm{hrs}$ in prebiotic $] /[\Delta(\log C F U / m L)$ probiotic at 0 and $24 \mathrm{hrs}$ in glucose $]-[\Delta(\log \mathrm{CFU} / \mathrm{mL})$ non-probiotic at 0 and $24 \mathrm{hrs}$ in prebiotic] $/[\Delta(\log \mathrm{CFU} /$ $\mathrm{mL}$ ) non-probiotic at 0 and $24 \mathrm{hrs}$ in glucose]

\subsection{Statistical analysis}

Experiments were carried out in triplicate. Data were presented as mean value \pm standard deviation. For statistical analysis, IBM SPSS statistics 21 was used to perform the analysis of variance (ANOVA) followed by the least significant difference (LSD) test at a $5 \%$ level of significance.

\section{Results and discussion}

3.1 Proximate analysis and dietary fibre content of passion fruit and santol

Table 1 shows the proximate composition of the edible part of the passion fruit and santol. Apart from water content, total carbohydrate and fat were the main compositions of passion fruit at $15.44 \pm 1.18 \%$ and $10.24 \pm 0.29 \%$ wet basis. Whereas total carbohydrate was also a major component of santol fruit which was $12.75 \pm 0.21 \%$ fresh weight with few ash and protein content. When compared to the most studied yellow passion fruit (Passiflora edulis f. flavicarpa), purple passion fruit had more protein and fat content as previously reported (López-Vargas et al., 2013; Corrêa et al., 2016; dos Reis et al., 2018). Whereas this is the first report on the proximate composition of Thai nung cultivar. Santol fruit showed similar ash and protein content to those reported with slightly more fat content (Janick and Paull, 2008).

Table 1. Proximate analysis of the edible portions of passion fruit and santol

\begin{tabular}{ccc}
\hline g per 100 g wet basis & Passion fruit & Santol \\
\hline Moisture & 70.991 .20 & $82.46 \pm 0.28$ \\
Ash & $0.89 \pm 0.13$ & $0.52 \pm 0.01$ \\
Protein & $2.44 \pm 0.11$ & $0.47 \pm 0.00$ \\
Fat & $10.24 \pm 0.29$ & $3.81 \pm 0.16$ \\
Total carbohydrate & $15.44 \pm 1.18$ & $12.75 \pm 0.21$ \\
\hline
\end{tabular}

The fibre content of both selected fruits is shown in Table 2. Total dietary fibre (TDF) by summation was $44.81 \pm 0.77 \%$ and $26.82 \pm 1.05 \%$ of dry weight for passion fruit and santol, respectively. Insoluble dietary fibre (IDF) represents a dominant constituent compared to the soluble dietary fibre (SDF) in both fruits. However, santol fruit fibre is nearly equal between IDF $(14.00 \pm 2.20 \%)$ and SDF $(12.82 \pm 2.03 \%)$ which gave the IDF: SDF ratio 1.09. This ratio in the range of 1.0 to 2.3 represents the balance of both types of fibre on the physiological effect in the intestine as whole fruits and fruit by-products are well recognized for their fibre content (Wanlapa et al., 2015). Both passion fruit and santol are rich in dietary fibre compared with other tropical fruits such as sapota (Achras sapota), guava (Psidium guajava), and date (Phoenix dactylifera) (Ramulu and Rao, 2003). Though the total fibre content of passion fruit was higher than santol, passion fruit was

Table 2. Dietary fibre content (dry basis) of the edible portions of passion fruit and santol

\begin{tabular}{lcc}
\hline Dietary Fibre \% (w/w) & Passion fruit & Santol \\
\hline Insoluble fibre (IDF) & $43.09 \pm 2.34$ & $14.00 \pm 2.20$ \\
Soluble fibre (SDF) & $1.71 \pm 0.54$ & $12.82 \pm 2.03$ \\
Total dietary fibre & $44.81 \pm 0.77$ & $26.82 \pm 1.05$ \\
IDF:SDF ratio & 25.2 & 1.09 \\
\hline
\end{tabular}


responsible for insoluble fibre content as previously reported of Passiflora edulis var flavicarpa (Chau and Huang, 2004). This may be due to its consumable seed coat mixed in puree or juice.

\subsection{Fruit polysaccharide extraction}

Extraction by hot water presented in this study yielded in its dry basis were $16.47 \%$ and $25.24 \%$ for passion fruit and santol, respectively. In this study, passion fruit was defatted in ethanol because lipid is able to interfere with water permeation (Azmi et al., 2012). Moreover, to mimic the edible fruit, the ethanol precipitation step was not included while the purification step could be applied to minimize those characteristics of dietary fibre in the furthered experiment.

\subsection{Functional properties of fruit polysaccharide}

The functional properties were shown in Figure 1. The hydrating possessions of water-soluble polysaccharide were in small amounts with undetected swelling capacity (data not presented). Santol fruit polysaccharide displayed an oil holding capacity of $4.43 \pm 0.93 \mathrm{~g}$ of oil held per $\mathrm{g}$ of the sample compared with the passion fruit polysaccharide which was $2.62 \pm 0.10 \mathrm{~g}$ of oil held per $\mathrm{g}$ of sample. There are some technological properties that offer physiological functionality including WHC, OHC, and CEC (Elleuch et al., 2011). Water-extractable polysaccharide from passion fruit seed and pulp depicts lower WHC and higher $\mathrm{OHC}$ than dietary fibre powder (López-Vargas et al., 2013). Santol fruit polysaccharide had superb OHC at $4.43 \mathrm{~g}$ oil per $\mathrm{g}$ fibre when compared to other tropical fruits such as mango at 1.6, pineapple at 0.7 , and guava at $0.7 \mathrm{~g}$ oil per $\mathrm{g}$ fibre (Martínez et al., 2012). Oilholding capacity is the amount of oil retained by the fibre; thus, fibre can bind with fat resulting in the

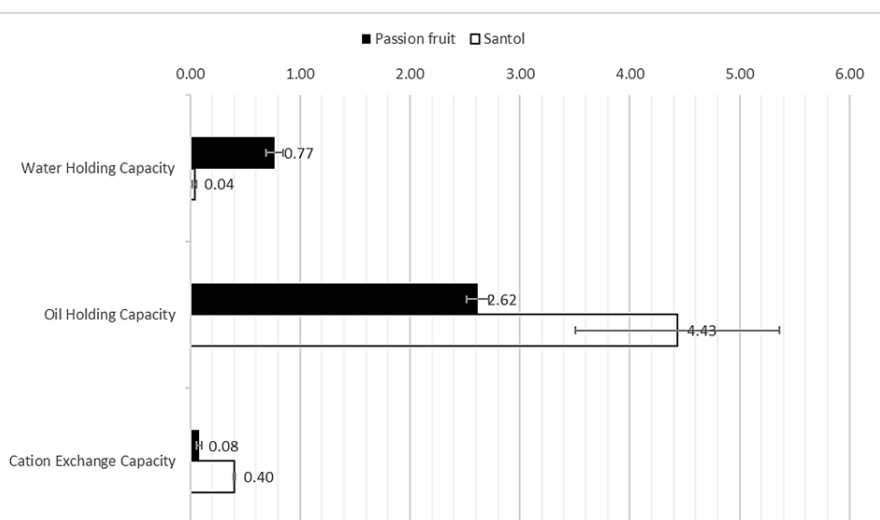

Figure 1. Functional properties of fruit polysaccharide from passion fruit ( $\square)$ and santol ( $\square$ ) are represented as water holding capacity, oil holding capacity, and cation exchange capacity. The polysaccharides of santol have better oil holding and cation exchange capacity than the polysaccharide of passion fruit, however it less preferable for oil holding capacity. prevention of fat loss during food processing and reducing serum cholesterol levels (Luo et al., 2017).

\subsection{Prebiotic properties of fruit polysaccharide}

Figure 2 shows the prebiotic activity score (PAS) derived from the number of bacterial cells enumeration by viable plate count (Table 3 ). The proliferation of probiotic strains was excellent on passion fruit polysaccharide with a maximum value of $3.45 \log \mathrm{CFU} /$ $\mathrm{mL}$ differing between $0 \mathrm{hr}$ and $24 \mathrm{hr}$ for $B$. longum and $3.29 \log \mathrm{CFU} / \mathrm{mL}$ for L. acidophilus, though it also supports the growth of $E$. coli. Hence the key qualifier for a prebiotic effect is the selectivity of fermentable dietary fibre. Prebiotic activity score (PAS) was developed to evaluate preliminarily selectivity of the substrate in promoting the growth of intestinal bacteria associated with health and pathogenic bacteria (Huebner et al., 2007). The PAS values of passion fruit polysaccharide were the lowest score of -0.25 on $L$. acidophilus and of -0.23 on B. longum. Whereas the santol polysaccharide selectively supports the growth of probiotic bacteria and resulted in the highest PAS at 0.10 on L. acidophilus. The score was used to assess the prebiotic effect of the variety of fruit dietary fibre for example guava displayed the PAS at 0.13 on L. acidophilus, enzyme hydrolysate of longan displayed the PAS at 1.69 and 1.44 for L. acidophilus La5 and Bifidobacterium lactis Bb12, respectively (Thuaytong and Anprung, 2011; Thitiratsakul and Anprung, 2014). In this study, PAS of hot water fibre-derived extraction may be the effect of sugar, which are more preferable and non-selective on established microorganisms. Hence, the fibre extracts are able to promote $E$. coli as well.

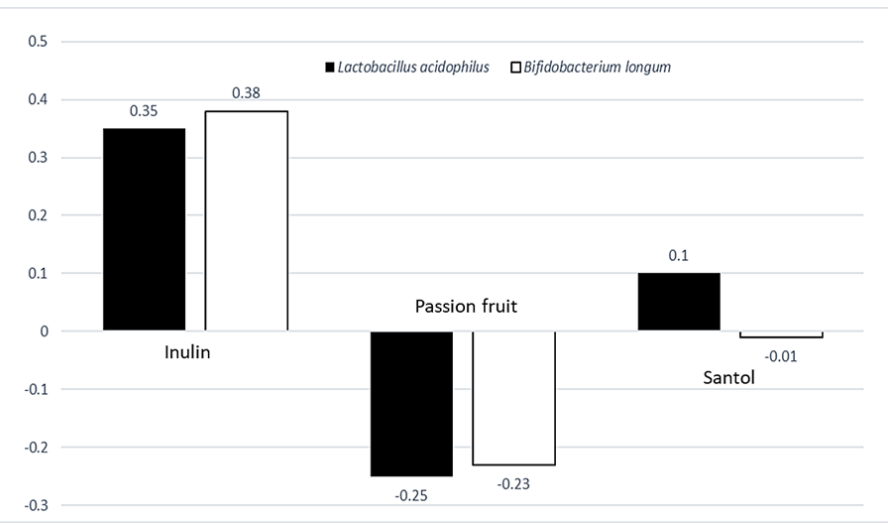

Figure 2. Graphical representation of prebiotic activity scores of L. acidophilus ( $\mathbf{\square})$ and B. longum ( $\square$ ) on passion fruit and santol polysaccharide.

Accordingly, passion fruit polysaccharide can support the proliferation of all tested microorganisms in a great manner including on E. coli. As a result, passion fruit polysaccharide may not be suitable for prebiotic effects, but it has the potential to be a probiotic carrier where further research needed. While santol fibre can be used to support the selective growth of $L$. acidophilus not 
statistically different from inulin, the commercial prebiotic. However, the same substrates may be highly specific to a different genus of microorganisms, future research should be conducted to evaluate the dynamics of intestinal microbiota (Bindels et al., 2015; FigueroaGonzalez et al., 2019).

Table 3. Proliferation of tested microorganisms on fruit polysaccharide, difference in bacterial growth between $0 \mathrm{hr}$ and 24 hrs $(\log \mathrm{CFU} / \mathrm{mL})$

\begin{tabular}{lccc}
\hline Bacterial culture & Inulin & $\begin{array}{c}\text { Passion } \\
\text { fruit }\end{array}$ & Santol \\
\hline Escherichia coli & $1.39 \pm 0.69^{\mathrm{b}}$ & $2.64 \pm 0.39^{\mathrm{a}}$ & $1.82 \pm 0.64^{\mathrm{a}}$ \\
Lactobacillus acidophilus & $3.29 \pm 0.42^{\mathrm{a}}$ & $3.29 \pm 0.40^{\mathrm{a}}$ & $3.16 \pm 0.63^{\mathrm{a}}$ \\
Bifidobacterium longum & $3.46 \pm 0.54^{\mathrm{a}}$ & $3.45 \pm 0.36^{\mathrm{a}}$ & $2.87 \pm 0.54^{\mathrm{a}}$ \\
\hline
\end{tabular}

Values are expressed as mean \pm SD. Values with different superscript within the same row are significantly different $(\mathrm{p}<0.05)$.

\section{Conclusion}

Fruit dietary fibre is attractive as a conventional substance for its prebiotic effect. The present study demonstrated the supportive effect of passion fruit and santol polysaccharide on the growth of L. acidophilus and $B$. longum as well as inulin. The prebiotic activity score of santol polysaccharide indicated its selectivity to promote the growth of $L$. acidophilus. While passion fruit polysaccharide can promote the growth of tested microorganisms with a low selectivity rate, this may be appropriate for auxiliary probiotic strains as food matrix in probiotic food formulation. Moreover, the oil holding capacity of water-extractable dietary fibre from both types of fruits showed the potential use in absorbing the fat content. These results may ensure the fruit fibre, as a whole or by-product, is an appropriately functional ingredient in modern cuisine.

\section{Conflict of interest}

The authors declare no conflict of interest.

\section{Acknowledgments}

This research project is supported by the Faculty of Pharmacy, Mahidol University.

\section{References}

Al-Sheraji, S.H., Ismail, A., Manap, M.Y., Mustafa, S., Yusof, RM. and Hassan, F.A. (2012). Fermentation and non-digestibility of Mangifera pajang fibrous pulp and its polysaccharides. Journal of Functional Foods, 4(4), 933-940. http://doi.org/10.1016/ j.jff.2012.07.001

Al-thubiani, AS. and Khan, M.S.A. (2017). The prebiotic properties of date palm (Phoenix dactylifera L.) seeds in stimulating probiotic Lactobacillus. Journal of Pure and Applied Microbiology, 11(4), 16751686. http://doi.org/10.22207/JPAM.11.4.05

Anantachoke, N., Lomarat, P., Praserttirachai, W., Khammanit, R. and Mangmool, S. (2016). Thai fruits exhibit antioxidant activity and induction of antioxidant enzymes in HEK-293 cells. EvidenceBased Complementary and Alternative Medicine, 2016, 6083136. http://doi.org/10.1155/2016/6083136

Azmi, A.F., Mustafa, S., Hashim, D.M. and Manap, Y.A. (2012). Prebiotic activity of polysaccharides extracted from Gigantochloa levis (Buluh beting) shoots. Molecules, 17(20), 1635-1651. http:// doi.org/10.3390/molecules 17021635

Bindels, L.B., Delzenne, N.M., Cani, P.D. and Walter, J. (2015). Towards a more comprehensive concept for prebiotics. Nature Reviews Gastroenterology and Hepatology, 12(5), 303-310. http://doi.org/10.1038/ nrgastro.2015.47

Brownlee, I.A. (2011). The physiological roles of dietary fibre. Food Hydrocolloid, 25(2), 238-250. http:// doi.org/10.1016/j.foodhyd.2009.11.013

Chau, C.F. and Huang, Y.L. (2004). Characterization of passion fruit seed fibres-a potential fibre source. Food Chemistry, 85(2), 189-194. http:// doi.org/10.1016/j.foodchem.2003.05.009

Corrêa, R.C., Peralta, R.M., Haminiuk, C.W., Maciel, G.M., Bracht, A. and Ferreira, I.C. (2016). The past decade findings related with nutritional composition, bioactive molecules and biotechnological applications of Passiflora spp. (passion fruit). Trends in Food Science and Technology, 58, 79-95. http:// doi.org/10.1016/j.tifs.2016.10.006

dos Reis, L.C., Facco, E.M., Salvador, M., Flôres, S.H. and de Oliveira Rios, A. (2018). Antioxidant potential and physicochemical characterization of yellow, purple and orange passion fruit. Journal of Food Science and Technology, 55(7), 2679-2691. http://doi.org/10.1007/s13197-018-3190-2

Elleuch, M., Bedigian, D., Roiseux, O., Besbes, S., Blecker, C. and Attia, H. (2011). Dietary fibre and fibre-rich by-products of food processing: Characterisation, technological functionality and commercial applications: A review. Food Chemistry, 124(2), 411-421. http://doi.org/10.1016/ j.foodchem.2010.06.077

Fasawang, N. and Anprung, P. (2014). Antioxidant and prebiotic activity of enzymatically hydrolyzed lychee fruit pulp. Food Technology and Biotechnology, 52 (3), 300-306.

Figueroa-Gonzalez, I., Rodriguez-Serrano, G., Gomez- 
Ruiz, L., Garcia-Garibay, M. and Cruz-Guerrero, A. (2019). Prebiotic effect of commercial saccharides on probiotic bacteria isolated from commercial products. Food Science and Technology, 39(30), 747 -753. http://dx.doi.org/10.1590/fst.07318

Fissore, E.N., Santo Domingo, C., Gerschenson, L.N. and Giannuzzi, L. (2015). A study of the effect of dietary fibre fractions obtained from artichoke (Cynara cardunculus L. var. scolymus) on the growth of intestinal bacteria associated with health. Food and Function, 6(5), 1667-1674. http:// doi.org/10.1039/c5fo00088b

Gibson, G.R., Hutkins, R., Sanders, M.E., Prescott, S.L., Reimer, R.A., Salminen, S.J., Scott, K., Stanton, C., Swanson, K.S., Cani, P.D. and Verbeke, K. (2017). Expert consensus document: The International Scientific Association for Probiotics and Prebiotics (ISAPP) consensus statement on the definition and scope of prebiotics. Nature Reviews Gastroenterology and Hepatology, 14(8), 491-502. http://doi.org/10.1038/nrgastro.2017.75

Horwitz, W. and Latimer Jr., G.W. (2012). Official Method of Analysis of AOAC International. 19th ed. Maryland: AOAC.

Huebner, J., Wehling, R.L. and Hutkins, R.W. (2007). Functional activity of commercial prebiotics. International Dairy Journal, 17(7), 770-775. http:// doi.org/10.1016/j.idairyj.2006.10.006

Janick, J. and Paull, R.E. (2008). The Encyclopedia of Fruit and Nuts. Oxfordshire: CABI Publishing.

Lascano, R.A., Gan, M.G.L.D., Sulabo, A.S.L., Santiago, D.M.O., Ancheta, L.B. and Zubia, C.S. (2020). Physico-chemical properties, probiotic stability and sensory characteristics of Lactobacillus plantarum S20-supplemented passion fruit (Passiflora edulis $\mathrm{f}$. flavicarpa Deg.) juice powder. Food Research, 4(2), 320-326. http://doi.org/10.26656/fr.2017.4(2).295

Lim, S.Y., Tham, P.Y., Lim, H.Y., Heng, W.S. and Chang, Y.P. (2018). Potential functional byproducts from guava puree processing. Journal of Food Science, 83(6), 1522-1532. http:// doi.org/10.1111/1750-3841.14155

López-Vargas, J.H., Fernández-López, J., Pérez-Álvarez, J.A. and Viuda-Martos, M. (2013). Chemical, physico-chemical, technological, antibacterial and antioxidant properties of dietary fibre powder obtained from yellow passion fruit (Passiflora edulis var. Flavicarpa) co-products. Food Research International, 51(2), 756-763. http://doi.org/10.1016/ j.foodres.2013.01.055

Luo, X., Wang, Q., Zheng, B., Lin, L., Chen, B., Zheng, Y. and Xiao, J. (2017). Hydration properties and binding capacities of dietary fibres from bamboo shoot shell and its hypolipidemic effects in mice. Food and Chemical Toxicology, 109(Part 2), 10031009. http://doi.org/10.1016/j.fct.2017.02.029

Maria do Socorro, M.R., Alves, R.E., de Brito, E.S., Pérez-Jiménez, J., Saura-Calixto, F. and ManciniFilho, J. (2010). Bioactive compounds and antioxidant capacities of 18 non-traditional tropical fruits from Brazil. Food Chemistry, 121(4), 9961002. http://doi.org/10.1016/j.foodchem.2010.01.037

Martínez, R., Torres, P., Meneses, M.A., Figueroa, J.G., Pérez-Álvarez, J.A. and Viuda-Martos, M. (2012). Chemical, technological and in vitro antioxidant properties of mango, guava, pineapple and passion fruit dietary fibre concentrate. Food Chemistry, 135 (3), 1520-1526. http://doi.org/10.1016/ j.foodchem.2012.05.057

Nassar, Z., Aisha, A. and Majid, A.A. (2010). The pharmacological properties of terpenoids from Sandoricum koetjape. Webmed Central Complementary Medicine, 2010, 12.

Quirós-Sauceda, A.E., Ayala-Zavala, J.F., SáyagoAyerdi, S.G., Vélez-de La Rocha, R., SañudoBarajas, A. and González-Aguilar, G.A. (2014). Added dietary fibre reduces the antioxidant capacity of phenolic compounds extracted from tropical fruit. Journal of Applied Botany and Food Quality, 87, 227-233.

http://doi.org/10.5073/

JABFQ.2014.087.032

Ramulu, P. and Rao, P.U. (2003). Total, insoluble and soluble dietary fibre contents of Indian fruits. Journal of Food Composition and Analysis, 16(6), 677-685. http://doi.org/10.1016/S0889-1575(03) 00095-4

Requena, M.C., González, C.N., Barragán, L.A., Correia, T., Esquivel, J.C. and Herrera, R.R. (2016). Functional and physico-chemical properties of six desert-sources of dietary fibre. Food Bioscience, 16, 26-31. http://doi.org/10.1016/j.fbio.2016.08.001

Tadayoni, M., Sheikh-Zeinoddin, M. and SoleimanianZad, S. (2015). Isolation of bioactive polysaccharide from acorn and evaluation of its functional properties. International Journal of Biological Macromolecules, 72, 179-184. http:// doi.org/10.1016/j.ijbiomac.2014.08.015

Thitiratsakul, B. and Anprung, P. (2014). Prebiotic activity score and bioactive compounds in longan (Dimocarpus longan Lour.): influence of pectinase in enzyme-assisted extraction. Journal of Food Science and Technology, 51(9), 1947-1955. http:// doi.org/10.1007/s13197-014-1263-4

Thuaytong, W. and Anprung, P. (2011). Bioactive 
compounds and prebiotic activity in Thailand-grown red and white guava fruit (Psidium guajava L.). Food Science and Technology International, 17(3), 205-212. http://doi.org/10.1177/1082013210382066

Toobpeng, N., Powthong, P. and Suntronthiticharoen, P. (2017). Evaluation of antioxidant and antibacterial activities of fresh and freeze-dried selected fruit juices. Asian Journal of Pharmaceutical and Clinical Research, 10(9), 156-160. http://doi.org/10.22159/ ajpcr.2017.v10i9.19099

Verspreet, J., Damen, B., Broekaert, W.F., Verbeke, K., Delcour, J.A. and Courtin, C.M. (2016). A critical look at prebiotics within the dietary fibre concept. Annual Review of Food Science and Technology, 7, 167-190. http://doi.org/10.1146/annurev-food081315-032749

Wanlapa, S., Wachirasiri, K., Sithisamang, D. and Suwannatup, T. (2015). Potential of Selected tropical fruit peels as dietary fibre in functional foods. International Journal of Food Properties, 18(6), 1306-1316. http:// doi.org/10.1080/10942912.2010.535187

Wichienchot, S., Youravong, W., Prueksasri S. and Ngampanya, B. (2015). Recent researches on prebiotics for gut health in Thailand. Functional Foods in Health and Disease, 5(11), 381-394. http:// doi.org/10.31989/ffhd.v5i11.214 